\title{
Kirari as Autobiography in Hausa Praise Poetry
}

\section{Chaibou Elhadji Oumarou}

Department of English, Univerité Abdou Moumouni de Niamey, Niamey, Niger

Email:dmochaibouhaladou85@gmail.com

How to cite this paper: Oumarou, C. E. (2018). Kirari as Autobiography in Hausa Praise Poetry. Advances in Literary Study, 6, 120-134

https://doi.org/10.4236/als.2018.63010

Received: March 24, 2018

Accepted: July 10, 2018

Published: July 13, 2018

Copyright $\odot 2018$ by author and Scientific Research Publishing Inc. This work is licensed under the Creative Commons Attribution International License (CC BY 4.0).

http://creativecommons.org/licenses/by/4.0/

\begin{abstract}
This study shows that autobiography exists in oral civilizations by exploring Kirari in Hausa praise poetry. The study focuses on the forms of Kirari that clearly bring out the autobiographical elements that illustrate the autobiographer's conscious awareness of the singularity of his or her life and achievements and the uniqueness of their identity among the members of their community and/or profession. These forms of Kirari are identified in excerpts from Hausa hunters' heroic self-praise and from Bakandamiya by the singer Maman Shata Katsina.
\end{abstract}

\section{Keywords}

Hausa, Oral Autobiography, Kirari, Niger, Nigeria

\section{Introduction}

Autobiography has often been associated with literacy and literate societies. As a result, few researchers have attempted to locate it in oral civilizations. This study explores the autobiographical dimension of Kirari or self-praise in Hausa praise poetry. My purpose is first to draw the attention of scholars about the urgent need to collect and preserve Kirari because it is on the verge of extinction and second to show that autobiography exists in oral civilizations in general as well as in Hausa oral poetry. But prior to the exploration of Kirari, it is important to make a situational analysis of the autobiographical dimension of praise poetry in general.

\section{Praise Poetry as Autobiography}

In an analysis of the autobiographical components of the hunters' chant in Yoruba praise poetry, Alabi (2007: p.13) identifies many oral autobiographical traditions that include praise poetry, epic, the hunters' chant, testimonies, witches' and wizards' confessions, as well as the bridal chant in different parts of Africa. 
The Yoruba hunters, Alabi claims, “... function as autobiographers who chronicle and contest tales of the self, resistance, and emancipation about themselves and their communities". As a result, Alabi concludes, their chants “... question loudly the traditional definition of autobiography as stories of the self written by individuals. The chants also dispute the Eurocentric claim that autobiographies were not produced in Africa prior to colonization..." (p. 14; emphasis added; see also Oumarou, $1994^{1}$ ).

In addition, Alabi equals these hunters' chants to oral self-portraits which carry the autobiographers' subjectivity. The latter is translated through the autobiographer's "praising and celebrating himself and his achievements, turning even seemingly negative qualities into enviable characteristics in his laudatory tradition” (p. 14). This description echoes Smith's concept of the modern autobiographer's sense of a “unique historical identity” (qtd in Braendlin, 1994: p. 9) and Gusdorfs notion of a "... conscious awareness of the singularity of individual life" (ibid.) within the community and/or profession. There is also the shared identity of the speaking or acting subject in the form of the first person pronoun "I" and the persona that expresses the experience of "I". Philippe Lejeune (qtd by Oumarou, 1994: p. 21) calls that sharing of identity "the autobiographical pact". It seals the conditions under which the reader or listener will interpret the form and content of the oral or written autobiography.

Based on his analysis of the Yoruba hunters' chant, Alabi explains that "The repeated 'P refers to the [oral] poetchanter/autobiographer consistently, and from this reference to the individual, the story changes to the 'I' and 'eye' of the chanter's community and ancestry" (p. 18; emphasis added). The change from the individual "I" to the communal "I" and "eye" reinforces the link between the oral praise singers and their communities. In that sense (Anyindoho, 1986: p. 12) reminds us that "The poetry of print is the domain of eyewitness, the poetry of sound [oral poetry], the domain of the earwitness..." (emphasis added). In his Bakandamiya, the praise singer Maman Shata Katsina confirms Anyindoho's claim through his call to his royal audience to lend him their ears and become his ear witnesses: "Princes, I hope and think that you will lend me your ears, land listen to my song" (emphasis added).

In "Poetry as Autobiography: Society and Self in Three Modern West African Poets”, Knipp (1986: p. 41) also demonstrates that poetry is indeed one of the varieties of autobiography that display strong links between the experiences of the autobiographical personas and the ones of their communities. So that "poet after poet these experiences possess a communality that emerges as pattern or myth". As a consequence, Knipp concludes, these poets "make poetry out of their lives and autobiography out of their poems [so that] as members of the educated elite, their experiences are representative of that class. Thus to the degree that they speak of themselves, they speak of their peers". The point of this study is that the experiences of the oral praise singers are also representative of

${ }^{1}$ L'autobiographie ne fait pas partie de la culture des pauvres-Phillipe Lejeune. Je est un autre. Paris: Editions du Seuil, 1980; qtd by Oumarou (1994). 
their communities or classes almost in the same way as the modern poets are. For as (Anyindoho, 1986: p. 13) rightly argues, "Long before the writer poet became eyewitness, there was the oral poet as earwitness... (emphasis added). Many of our people do not have eyes to witness [by reading] the poetry of print, but they do have ears for the power of the sound and the sense of words".

(Anyindoho, 1986: p. 6) goes even further in his defense of the oral artist's originality and modernity based on his conviction that any form of oral art can be "both traditional and modern at the same time". This is why he provides insightful examples to question "the supposition that there is always something inherently more creative and more original in the thinking and execution of the act of creative writing as compared to the work of the oral artist". So like the modern poet who is supposed to represent the elite that make up his social class, the oral artist can also represent his social category, clan or profession.

For Alabi as well, there is no shadow of a doubt about the oral poets' representativeness; especially when they belong to specialized professions like the Hausa hunters "praise poets (Baum, 2016) or the Yoruba hunters" chants that constitute the corpus of his investigation. As a matter of fact, Alabi argues that

Some traditional professions even have autobiographical dimensions built into them. Hunting is one of these specialized professions with its own discourses and counter discourses typically developed in the autobiographical hunters chants. Among the Yorubas, it is called ijala. These hunters' chants are oral texts about self. They belong to a genre exclusive to hunters, and are performed on various occasions, including hunters' festivals, coronation ceremonies, weddings and other special gatherings (p. 13; emphasis added).

In the light of the above situational analysis on autobiography and its relation to praise poetry, this study explores Kirari or self-praise in Hausa praise poetry and shows also that autobiography exists in societies with oral civilizations. It therefore focuses on the forms of Kirari that clearly bring out the autobiographical elements that illustrate the autobiographer's conscious awareness of the singularity of his or her life and achievements and the uniqueness of their identity among the members of their community and/or profession. These forms of Kirari are identified in excerpts from Hausa hunters' heroic self-praise (Baum, 2016) ${ }^{2}$ and from Bakandamiya by the singer Maman Shata Katsina.

\section{Kirari as Autobiography in Hausa Praise Poetry}

What better narrative authority... than that of a raconteur detailing first-hand experience?-Olakunle George ${ }^{4}$

\footnotetext{
${ }^{2}$ The excerpts about Hausa hunters' praises are taken from the manuscript article by Baum (2016: p.1) titled: "Self-Praise and Performance in the Heroic Praise-epithets of Hunters in Hausaland" sent to me in 2016 for a peer review.

${ }^{3}$ The Bakandamiya or Master Song by Alhaji Maman Shata and Dan Anace are quoted from Linda Hunter and Chaibou Elhadji Oumarou. Aspects of the Aesthetics of Hausa Verbal Art. Köln: Rüdiger Koppe Verlag, 2001: p.35, 42-45.

${ }^{4}$ George, O. 1997. Compound of spells: the predicaments of D. O. Fagunwa (1903-63). IN: Research in Africa Literatures 28 (1): 79-97.
} 
There are so many definitions of the term Kirari (Skinner, 1980; Furniss, 1996; Mahamane, 2012; Bunza \& Noofal, 2013) that Mode (2015) describes its nature as confusing. He attributes this confusing nature of the epithet to the fact that its features and characteristics are also found in other Hausa oral genres such as take and waka. Graham Furniss (1996: p. 73) adds that "Kirari and take have generally been represented as 'praise-epithet' and 'drummed equivalents of verbal epithets' respectively, although there is a confusing variety of usage in the literature (emphasis added) as between these terms and a further term, waka 'song'". What these different terms have in common, Furniss comments after Edward L. Powe, is that they help the speaking subject and the audience for the identification of self through a display of imagery and patterns of rhythmic language. This capacity to help in the identification of self in its complex nature is a major distinguishing feature of Kirari as a genre in Hausa praise songs. But Kirari as hunters' autobiography is on the verge of extinction.

As a matter of fact, according to Baum (2016), Kirari as autobiography is difficult to come across today because the traditional hunting culture is no longer observed in Hausaland in particular. As a consequence, Kirari as self-praise epithets are now "only delivered on request" in the Hausaland. There is therefore an urgency to collect, transcribe, translate and interpret any materials relating to the genre. This explains my interest in the self-praise of Na-Ahmadu (Baum, 2016) below. This autobiographical performance by Na-Ahmadu belongs to the Hausa hunting culture of self-praise. Note for instance that in his Bakandamiya Shata points out that Dalla Hill and Gwabron Dutse were the abode of Tsunburbura, Barbushe, Gagiwa and Kano. The latter were all "hunters of elephants and had no equals". This Kirari addressed to the famous hunters is a biography that completes Shata's contextual autobiography.

Through Kirari as self-praise or autobiography, Hausa hunters highlight their courage and courteousness. In so doing, Baum (2016: p. 1) argues, "Their intent [is] to celebrate themselves, recounting their bravery and heroic accomplishments..." (emphasis added). The following is an excerpt from a long autobiographical Kirari by the famous hunter Na-Ahmadu interviewed by Baum at Abatuwa in Katsina in 2012. The original excerpts, both in Hausa and English, are from Baum's Manuscript:

Excerpt No 1: This excerpt represents take as an autobiographical sub-genre of Kirari. Baum (2016: p. 14) reports that Graham Furniss identifies take "as introductory 'catch-phrases' and incitement headlines for Kirari, a lengthier form of praise poetry in Hausa. Take are, therefore, the 'metonymic representations' of lengthier Kirari declamations and songs". The following take are self-praises by the performer Na-Ahmadu for himself, hence their autobiographical dimension.

Cizgau nike bata karawwa [...]

Sayi bakin karhe

Ni ar Na-Ahmadu Kwabre [...]

$\mathrm{Ni}$ ar karen gudun ruwan dan gitta [...] 
Nine garo dame farauta

Kukkui nike, kuka mai gari ya hwadi

Sakandimi nike sai mai burat [...]

$\mathrm{Ni}$ ar Kura kanuri karen [...]

Ni ar gagara daku magajin Musa [...]

I am the stretch that never gets yanked to its furthest limit [...]

I am Sayi the black iron

I am the battle axe that the dog flees from [...]

I am garo that disrupts hunting

I am the dog that barks when the district head falls

I am the metal hefted axe worthy of only the brave [...]

I am the precarious and ferocious hyena [...]

I am the unconquerable descendant of Musa.

Excerpt No 2: This excerptis also an autobiographical take. It represents what Baum calls "relative eulogues". The latter "relate the [autobiographical performer] with people who are connected to him by blood, marriage, friendship, or other forms of relationships" (Tsoho qtd in Baum, 2016: p. 15):

Na Manu da Mani $[\ldots]$

Ni ar ba mamaki kanen Dan Iya [...]

$\mathrm{Ni}$ ar mai gudun gudu

Uba na Hayatu dan-tauri da yacci Maradi

Ni ar kahurin kare dan Hima

$\mathrm{Ni}$ ar gagara daku magajin Mani

Ni ar mai gudun gudu uba na Hayatu

Mai cigiyar hwada uban yan-tauri

Ar na wacci Maradi [...]

Ni ar gagara daku magajin Mani [...]

Ni ar Na-Ahmadu Kwabre

Ni ar ba mamaki kanen Dan Iya [...]

Kuma ni ar kura kahurin kare na malan Mamman

Kuma ni ar kura kahurin kare mijin Hanna mai ban tsoro

Brother of Manu and Mani [...]

I am the most incredible Dan Iya's brother [...]

I am the one who doesn't stand down

The father to Hayatu dan-tauri who conquered Maradi [...]

I am the undefeatable heir of Mani [...]

I am the one who doesn't turn his back, the father of Hayatu

One that seeks and pays for a fight, the father of 'yan-tauri

I am the fiercest who conquered Maradi [...]

I am the insuperable descendent of Mani [...]

I am Na-Ahmadu Kwabre

The most astounding brother of Dan Iya [...] 
And I am the hazardous and violent hyena, a relative to Malan Mamman

And I am the deadliest and furious hyena, the husband to the dreadful Hanna

Like in any autobiographical performance, the persona "I" and the hunter Na-Ahmadu, who eulogizes himself, are the same. The persona is therefore the one who "owns and tells the story, and his enactment magnifies his power" (Baum, 2016: p. 13; emphasis added). In the article titled, "The way I heard it was..." Myth, Memory, and Autobiography in "Storyteller and The Woman Warrior", Lappas (1994: p. 59) is also of the opinion that autobiography turns the autobiographical subject into the source of creative authority and an expression of an independent and confident self. This may explain why, according to Barrett J. Mandel (qtd by Braendlin, 1994: p. 17), "Readers turn to autobiography to satisfy a need for verifying a fellow human being' experience of reality". In doing so, their intention is to learn from that experience. It therefore becomes reassuring for them to see the author, the narrator, and the protagonist share the same identity in modern as well as in oral autobiography.

The repetition of " $I$ am" in the hunters' praise song foregrounds not only the authority of the autobiographer, but also the importance of both the persona and the praise-singer to himself and to his community. The last line of excerpt No1 also draws attention to the autobiographer's family line: "I am the unconquerable descendant of Musa". This connection, expanded to more family members in excerpt No 2, creates a family genealogy that makes the autobiographical text both individual and familial; and, by extension, communal. It also demonstrates that his heroic qualities are not removed from the heroic nature of his family: "a family that had already carved an heroic niche in the annals of time" (Baum, 2016: p. 16; emphasis added). The individual nature of this oral text is however manifested through the forceful repetition of " $I$ am". This becomes Na-Ahmadu's signature throughout his lengthy performance. In other words, the signature confers authority or authorship to the person who is the carrier of the autobiographer's experiences and the ones of his family and community.

But unlike written autobiography where the reader may be alone in appreciating the quality of the message, both in terms of aesthetics and content, each self-praise performance is a unique experience for both the self-praise performer and the audience. It is therefore during that unique performance that the audience can appreciate the autobiographical quality of the praise epithets. In his analysis of the Yoruba hunters' chants in performance, Alabi (2007: p. 18) notices an added advantage of an autobiographical performance as follows:

The audience can see [the oral autobiographer] ... as he represents himself, his family, and associates. There is much that we may not apprehend in the chant unless we can witness its performance. First, it is in the performance of the [song/self-praise] that we, the audience, will meet the performer/autobiographer. This is very crucial because the performer is essential- 
ly chanting his story and produces meaning by his tone and intonation. The voice is particularly noteworthy because of the mode of performance. As audience members, therefore, we do not just get the oral text, we see the performer, and by merely looking at him, we can corroborate some of the things he says about himself...

Being able to corroborate some of the things the autobiographical performer says is crucial because even in the written autobiography the frontier between truth and lie or between reality and fiction is blurred. In fact, critics have challenged the claim of autobiography to truth by stressing the fact that the rhetorical devices used in fiction also informed autobiography as well as autobiographical performance. They have concluded that in many respects, "fiction and autobiography were coterminous". A well-known similar rhetorical device used in Hausa verbal art is hyperbole defined as a "bold overstatement, or extravagant exaggeration of fact" (Abrams, 1988: p. 80). Other poetic devices are also used by Na-Ahmadu Kwabre in his heroic chants (Baum, 2016: pp. 14-22). But this is not a stylistic study of Kirari. Rather, I am concerned here only with Kirari as autobiography and with its sub-genres such as take and devices like hyperbole that call attention to the autobiographical dimension of self-praising.

Maman Shata Katsina also uses hyperbole and take in his Bakandamiya or master song to draw attention to himself through his autobiographical persona. Bakandamiya is a term used for a Hausa poetic masterpiece, often by the poet himself as it is the case with Shata. Muhammed (qtd by Hunter \& Chaibou, 2001: p. 35) analyses four compositions considered as "Bakandamiya”. These compositions are: Shata Katsina's Bakandamiya; Ibrahim Narambada’s Bakandamiya; Mahammadu na Birnin Gwari's Gangar Wa'azu or "The Drum of Admonitions" and Dan Anace's Shago. Note that Narambada did not call his song Bakandamiya by himself, but many critics later have. As mentioned earlier, I am mostly concerned in this study with Shata's Bakandamiya. Muhammed (qtd by Hunter \& Chaibou, 2001: p. 36) notes that "each Bakandamiya is dynamic in composition in that it keeps growing until the poet dies or until similar catastrophe occurs" (emphasis added). This also explains why each performance is unique.

Mohammed's definition is confirmed by Shata who defines his Bakandamiya as "a poem which [he] regards as his own favorite song, composed solely for himself, and in his composition he includes 'expressions which show how satisfied [he] is with himself, with his art, and with his world, as well as how defiant he is of contrary expectations in his life as a praise-singer"' (Hunter \& Chaibou, 2001: p. 35; emphasis added). This master song contains Shata's self-praise and so does Narambada's. While Dan Anace has qualified his master song as uwaw wakoki ("mother of songs") Narambada has also called his uwam mayyan wako$k i$ ("mother of great songs"). These expressions are like take or praise songs to the term Bakandamiya in Hausa, denoting its complexity and size as well as its importance in the eyes of the artists. 
A common feature of Bakandamiya is its high dose of autobiographical components in addition to biographical information and history. Shata's Bakandamiya has all these three features. For example, Hunter \& Chaibou (2001: p. 47) state that his

Bakandamiya is a biography in miniature. Shata traces his own ancestry and career. ... In [this] song he notes that he started singing as a hobby, that drumming is not his inheritance. His early career was a kola nut seller, and he alludes to that period when he compares himself to marsa, the biggest kola nuts. He began singing during this time in contests between boys and girls held at the marketplace, and gradually began to sing professionally, traveling to various parts of northern Nigeria... Bakandamiya also has many allusions to the history of Kano... And the song is situated historically by reference to Emir Sanusi Maman. Furthermore, Shata exalts the Hausa language, "our language since our grandfather's fathers".

As this quotation makes it clear, Shata's Bakandamiya is autobiographical in many respects: it tells us how he began his singing career, what he was doing before and how he became a professional singer almost in chronological order. We also learn about his family's past as well as the history of Kano city. We finally note for instance that Dalla Hill was the abode of Tsunburbura, Barbushe, Gagiwa and Kano who "were hunters of elephants and had no equals". Since each performance is a unique experience, I propose below a 1967 performance. It is about Shata's Bakandamiya, translated from Hausa into English by (qtd here in Hunter \& Chaibou, 2001: pp. 42-45). This performance includes Shata's autobiography, a biography of some hunters and patrons and the history of the city of Kano. The last two elements relate to his social and cultural context. The latter in turn provides a background to Shata's autobiography, a welcome historical anchorage.

Bakandamiya: This is a 1955 Hausa performance. The English version is a translation by Abdulkadir (qtd in Hunter \& Chaibou, 2001: pp. 42-45) of a 1967 Hausa performance. The difference in the two performances, as reflected in the translation, is a confirmation that each performance is unique and this is the reason why I decided to leave them side by side for researchers to appreciate the differences.

Alo, alo, mai ganga ya gode,

Yaran mai ganga sun gode,

Na kama Bakandamiya,

$\mathrm{Na}$ dauki abin de na dama ya dame ni.

Alo, alo, mai ganga ya gode,

Yaran mai ganga sun gode.

$\mathrm{Ni}$ fa ba abin da ya daman sai gangan nan,

Alo, alo, mai ganga ya gode,

Yaran mai ganga sun gode. 
Tausa a hankali, taho kadan kadan,

Ko dan kidan ku kai gado ni ban gada ba.

Roko shigar shi nai,

Ai na shige shi duk na gagari ya yan gado,

Alo, alo, mai ganga ya gode,

Yaran mai ganga sun gode.

Yanzu ma kamar mu ake so,

An ko ka sa.

Alo, alo, mai ganga ya gode,

Yaran mai ganga sun gode.

Amma ba rabo da gwani ba,

Kafin a maida gwani shi a mai ciwo.

Mai tumaki mai Jaki,

Mai tumaki mai Jaki,

Kanon Dabo Birni mai mata mai mota.

Alo, alo, mai ganga ya gode,

Yaran mai ganga sun gode.

Cinjimin gari mai Dala da Gwabron Dutse

Cinjimin gari mai Dala da Gwabron Dutse

Alo, alo, mai ganga ya gode,

Yaran mai ganga sun gode.

Kai sai da na cewa mutanen Birnin,

Na shedawa mutanen kauye,

$\mathrm{Na}$ ce roko ba gado nai ba,

Babu gadon ina, bare Modibo,

Gadon ba na uwarka ba,

Kana ba na uban ka ba,

Idan ka san dari da Kwabo Alhamdullahi

In dai ka san dari da Kwabo Alhamdullahi

Alo, alo, mai ganga ya gode,

Yaran mai ganga sun gode.

Nan wata rana Kano a birnin Dabo,

A'a an taba zama Birnin Dabo,

A zamanin Sanusi Mamman,

Burhan na Habu dan Abdu.

Sai na hada kayana na tashi,

Sai na koma Birnin Dikko,

A Kastinanmu mu Birnin Shehu.

Sai na ji maroka na wata murna,

Shegen nan Shata ya tashi,

Segen nan Shata ya tashi,

To, tunda ya tashi a Birnin Dabo,

Wannan da ya yi assar birni, 
$\mathrm{Ku}$ je na ji na yi assar birni,

Ai, ku kuma kun yi asarar waka

Alo, alo, mai ganga ya gode,

Yaran mai ganga sun gode.

Kai na yi wata shiga sai na komo,

$\mathrm{Na}$ tafi na yi wata shiga sai na komo,

Ran juma'a ana bikin 'yan sarki,

Sai nazo bisa Yar mota ta,

Sai ko na rabe na aje yar mota ta,

Na rufe kaina na zo kallo.

$\mathrm{Ni}$ ishe diyan sarki an zauna,

Ga barwan sarki an zauna,

Ga bayin sarki an zauna,

Samari yan birni an zauna,

Ga matan birni kan benci

Ni ko na rufe kaina na zo kallo,

$\mathrm{Na}$ mami yan Sarki anai masu Garaya tan fal yan Babule

Alo, alo, mai ganga ya gode,

Yaran mai ganga sun gode.

Da ga can na fito sarari,

Nace musu kun ga rashin Shata mai waka

Dan ba rabo da gwani ba,

Kafin a maida gwani shi a mai ciwo

Ko da goro akwai marsa,

Ko da a cikin mawaka akwai su,

Ni ke shuri dare guda yaka girma.

Allah ya yarda, har yau,

Ni ke yi, ku ko baku samo canji na ba,

Bare in zauna, wai har in ce zan huta,

In dai samu in sarara,

Wane hutu Shata, ai kai ne.

Idan na fara Bakandamiya

Ji nake kamar Malami gwanin tafsiri,

Malam amma fa gwani,

Yaja baki ya fasa ba tare da jin tsoro ba.

Don ba'a gwaninta da tsoro Malam,

Mai tsoro ba shi gwaninta,

Kowa ne, ko kuma dan wa.

Alo, alo, mai ganga ya gode,

Yaran mai ganga sun gode.

Ran nan ana bikin yan sarki

Sanusi ya tara marokan birni,

Ya kuma tara marokan kauye, 
Duk mun hallara kofar fada

Ranar da na mike, na yi kirari,

Alhaji mun gode wa Allah,

Mun gode wa Rasullahi,

Ranar da na hana Hamisu,

Na kwabi caji, na dangware Dabalo, ya daina

Na kyale banja da kukuma, wargin yara ne,

Suci abinci, Sannan, su sa shakwara,

Su yi jampa,

Su sami kudi su yi auren zamani.

Alo, alo, mai ganga ya gode,

Yaran mai ganga sun gode.

Ran nan ga inda giwa ta tashi,

Ga mai kare yana kallon ta,

Yai tsaye ba jin kirari nai ba,

A nan na ga yai tsaye ban ji kirari nai ba,

Alo, alo, mai ganga ya gode,

Yaran mai ganga sun gode.

"Alo", "Alo", the singer expresses his gratitude

and so [do] the chorus.

I started Bakandamiya and embraced the thing

that interests me most [Shata].

"Alo", "Alo", the singer expresses his gratitude and so [do] the chorus [chorus].

As for me nothing interests me except my singing,

Beat your drum carefully,

Play slowly and carefully,

For drumming is your inheritance but not mine [Shata].

I started singing as a hobby,

Certainly I started it as a hobby and outshined the professionals;

Now it is my match they search for and have woefully failed,

"Alo", "Alo", the singer expresses his gratitude and so [do] the chorus.

It is not parting with a hero that is painful,

But filling the gap that he created.

The city of sheep and donkeys

The city of sheep and donkeys,

Kano the city of Dabo, of beautiful women and cars,

The great ancient city of Bagauda has no equal.

Kano the huge city with Dala and Gwabron Dutse.

Let everybody know that Dala and Gwabron Dutse housed Tsunburbura,

It was the seat of Barbushe, Gagiwa and Kano;

They were hunters of elephants and had no equals.

Now they left, not even grass shelter there. 
I have made it clear to the city people,

I have made it clear to the village people,

I said to them: singing is not my father's profession,

It is neither my mother's nor that of Modibbo.

A profession that does not belong to your father,

Let alone your mother,

If you earn a penny and a half from it Alhamdullahi,

I repeat, if you earn a penny and a half from it Alhamdullahi.

The singer expresses his gratitude and so [do] the chorus

One day here in the city of Dabo,

I have ever lived in the city of Dabo,

During the reign of Sanusi Mamman,

Burhan father of Habu son of Audu,

Then I packed my belongings and left,

And returned to the city of Dikko,

Our Katsina, the city of Shehu.

My departure pleased the Kano singers,

They ganged up against me saying;

That bastard Shata had gone,

Good riddance Shata has left,

Ha! Since he left the city of Dabo,

No doubt has lost many good things.

Go your way; I am aware I missed the Kano City,

And Kano too had missed a famous singer,

And you also had missed my singing.

After six good months I staged a comeback,

I went away for six months,

And returned to the city of Dabo,

On Friday during the princes' wedding,

I sneaked in with my mini car

I took a corner and parked my mini car,

I put on a veil and joined the crowd.

I saw the princes were seated,

And the servants of the princes were also seated,

Even their slaves were seated,

The youth of the city also took their seats,

And so were the young girls of the city of Dabo,

I found the princes subjected to Garaya music as if they were Yan Babule

God forbid the palace become the arena of Yan Babule!

I have pondered and groaned

There and then I uncovered myself,

And said, You have now felt the absence of Shata, the singer.

Even among kolanuts there are Marsa, 
Well much more so among the singers,

Princes, I hope and think that you will lend me your ears,

And listen to my song.

It is not parting with the hero that is painful,

But filling the gap which he created.

Hausa-land recognized your anscestors,

Those on the other section of the city too accepted their leadership,

Their patience is very great,

It is not parting with the hero that is painful,

But filling the gap which he created.

Hausa-land recognized your anscestors,

Those on the other section of the city too accepted their leadership,

Their patience is very great,

They have no fear only respect for people's freedom.

I am singing for the royalists,

And I will sing in Hausa, our language since our grandfather's fathers,

Our fathers too and ours with sons and grandsons

And Kano is no doubt the embil of Hausa the city of Bagauda,

And every virtuous singer will do the same

Unceasingly, to demonstrate his pleasure for this great occasion.

Now let me list the bridegrooms for the audience,

They are Nadawaki, Maje, Ado, Barde and Shirama,

The day of the princes' wedding

During the reign of Sanusi Mamman,

Was engraved in my mind,

Sanusi invited all the village singers,

All of us gathered in the palace.

That day I rose and praised myself,

And praised God and his messenger,

That day I outshined Hamisu, outshined Caji and put Dabolo out of action,

They cast a spell on me but to no avail,

And had I prior knowledge,

I would have brought my billy-he goat, and my speckled fetish cock,

What! Would that I were able to know in advance,

I would have prepared for it.

I ignored banjo and guitar players,

Because they are insignificant musicians who,

Play for money, clothes to wear and a few pounds to get married.

That day I saw the elephant swaggering,

And the dog and its master watched,

There they remained motionless and speechless and unable to utter self-praise.

Your wedding delights everyone no one will dent it, 
Your wish had been fulfilled,

No one will be so willful, I can never forget,

Your gracious gifts showered on me,

By your relatives and friends,

That day Shata was given horses, gowns, gold and all the good things of this world,

I will never be a hen that eats and brushes its beak,

God bless you all, you have been generous,

You have sown good seeds

And you will reap its fruits.

Apart from autobiographical kirari and take, like the ones by $\mathrm{Na}$-Ahmadu and Shata Katsina discussed above, the autobiographical personas in these oral praises build themselves and their communities into biographical kirari and take. In this sense it is worth noting that Alabi (2007: p. 20) describes a similar process in his analysis of the Yoruba ijala chants. He concludes that it is "common to get glimpses into the personality of the chanter [or oral autobiographical persona] even when the chant celebrates someone else". This is precisely the case with Bakandamiya in which the oral praise singer Shata skillfully weaves his community's culture and history into biographical kirari as a solid foundation for his oral autobiography.

\section{Conclusion}

This paper has shown that autobiographical kirari helps in the identification of the performer through the kind of imagery and stylistic devices used to create specific mental pictures for the audiences to contemplate. Performers in general use repetition to create the desired imagery for the identification of their autobiographical personas. In the cases of the Hausa hunters' Kirari and Shata's Bakandamiya, the repetition of " $I$ am" or " $P$ ” beautifully serves this purpose. As a result, these devices function as the signatures of the Hausa oral autobiographer. The latter in turn is an illustration of the existence of autobiography in oral or semi-literate civilizations.

\section{References}

Abrams, M. H. (1988). A Glossary of Literary Terms. Fifth Edition. New York: Holt, Reneheart and Winston, Inc.

Alabi, A. (2007). I Am the Hunter Who Kills Elephants and Baboons: The Autobiographical Component of the Hunters' Chant. Research in African Literatures, 38, 13-23. https://doi.org/10.2979/RAL.2007.38.3.13

Anyindoho, K. (1986). Mythmaker and Mythbreaker: The Oral Poet as Earwitness. In E. Julien, M. Mortimer, \& C. Schade (Eds.), African Literature in Its Social and Political Dimensions (pp. 5-14). Washington DC: African Literature Association and Three Continents Press, Inc.

Baum, R. (2016). Self-Praise and Performance in the Heroic Praise-Epithets of Hunters in Hausaland. Journal of African Cultural Studies, Article ID: CJAC-2016-0002. 
http://mc.manuscriptcentral.com/cjac

Braendlin, B. (1994). Who Speaks (for) Autobiography? Re-Evaluating the Boundaries of Autobiography: Theory, Practice, Pedagogy. CEA Critic, 57, 9-19.

Bunza, A. M., \& Noofal, M. A. (2013). Ruwan Bagaja in Perspectives: Eight Decades of a Hausa Masterpiece in Prose (1933-2013). Special Edition. Cairo: UNICAIRO/UMYUK.

Furniss, G. (1996). Poetry, Prose and Popular Culture in Hausa. Washington DC: Smithsonian Institution Press.

Hunter, L., \& Chaibou, E. O. (2001). Aspects of the Aesthetics of Hausa Verbal Art. Koln: Rüdiger Koppe Verlag.

Knipp, T. R. (1986). Poetry as Autobiography: Society and Self in Three Modern West African Poets. In E. Julien, M. Mortimer, \& C. Schade (Eds.), African Literature in Its Social and Political Dimensions (pp. 41-50). Washington DC: African Literature Association and Three Continents Press, Inc.

Lappas, C. (1994). “The Way I Heard It Was...” Myth, Memory, and Autobiography in Storyteller and the Woman Warrior. Re-Evaluating the Boundaries of Autobiography: Theory, Practice, Pedagogy. CEA Critic, 57, 57-67.

Mahamane, A. (2012). Violence et paix dans les louanges des dignitaires hausa du Katsina. Etudes Sahéliennes: Epopée et violence dans les traditions africaines et européennes. Numéro special. Niamey: Université Abdou Moumouni.

Mode, M. A. (2015). Kirari (Epithet) as a Passing Device in Modern Hausa Prose from Northern Nigeria. International Journal of Humanities and Social Science Invention, 4, 18-24.

Oumarou, C. E. (1994). One Speaks, Another Writes: The Oral Autobiography of a Hausa Woman (1877-1951). Re-Evaluating the Boundaries of Autobiography: Theory, Practice, and Pedagogy. CEA Critic, 57, 57-67.

Skinner, N. (1980). An Anthology of Hausa Literature in Translation. Zaria: Northern Nigerian Publishing Co. Ltd. 